\title{
Interesting observations of beetles (Coleoptera) from Kaliningradskaya Oblast during 2018-2019, with supplementary pre-2018 data
}

\section{Интересные находки зкесткокрылых насекомых (Coleoptera) в Калининградской области в 2018-2019 гг., Аополненные данными до 2018 года}

\section{V.I. Alekseev \\ В.И. Алексеев}

Shirshov Institute of Oceanology, Russian Academy of Sciences, Nahimovskiy Prosp. 36, Moscow 117997 Russia. E-mail: alekseew0802@yahoo.com.

Институт океанологии им. П.П. Ширшова РАН, Нахимовский просп. 36, Москва 117997 Россия.

Key words: fauna, beetles, western Russia, new reports.

Ключевые слова: фауна, жесткокрылые, запад России, новые находки.

Abstract. 30 Coleoptera species are recorded from Kaliningradskaya Oblast, Russia. Ten species are reported for the first time, one of which, Leiopus femoratus, is expanding the areal from long distance, and two, Phaleria cadaverina and Trachys fragariae, from short range; four species, Lopheros rubens, Isorhipis marmottani, Ischnomera cyanea and Anaesthetis testacea, are probably aborigine with a cryptic habit of life, and three species, Suphrodytes figuratus, Hydrobius rottenbergii and Cotaster $\mathrm{cf}$. cuneipennis, are newly named for the region as a result of recent generic revisions. Representatives of Typhaeus and Combocerus, previously known by sporadic records during the 19th century are recorded, and $T$. typhoeus, Ph. cadaverina and $C$. cf. cuneipennis are registered in the Baltic region on the northeastern limit of the areal.

Резюме. Приводятся сообщения о 30 видах Coleoptera из Калининградской области. Впервые для изучаемой территории отмечено 10 видов, три из которых вероятно виды с расширяющимся ареалом (Leiopus femoratus дальняя инвазия, Phaleria cadaverina и Trachys fragariae - колонизация с малой дистанции); четыре предположительно аборигенные виды со скрытным образом жизни (Lopheros rubens, Isorhipis marmottani, Ischnomera cyanea, Anaesthetis testacea); три вида новые в регионе ввиду последних таксономических ревизий соответствующих родов (Suphrodytes figuratus, Hydrobius rottenbergii, Cotaster (f. cuneipennis). Представители двух родов, известных по единичным историческим сообщениям XIX века (Typhaeus, Combocerus), отмечены и подтверждены для изучаемой территории. Три вида $(T$. typhoeus, Ph. cadaverina, C. cf. cuneipennis) находятся в Калининградской области и восточной Прибалтике на самом северо-восточном краю ареала.

\section{Introduction}

The present study focused on additions of data to the knowledge of the fauna of Coleoptera in the southern Baltic region with special emphasis given to protected species, previously overlooked, insufficiently known, and those occurring at the border of their distribution range. The current occasional collecting in the region yields a number of the regionally new or rare findings annually. The reporting of the most interesting faunal material sampled and identified in 2018-2019 years in Kaliningradskaya Oblast and not included in other papers is the objective of the current contribution.

\section{Materials and methods}

The presented material was collected by the author during the years 2018-2019, although several specimens mentioned in the paper have been obtained earlier. Primarily, the localities spread in the western, southwestern and central parts of Kaliningradskaya Oblast were surveyed. Beetles were collected by hand, using entomological nets and pitfall traps. Sampling localities included different types of forests, parks, dry meadows, and the Baltic coastal area (the surf zone as well as the beach and bottom of the cliff). The examined material is deposited in the private collection of the author (Kaliningrad, Russia).

The specimens were identified based on the standard European identification key [Freude et al., 19651989; 2004], as well as additional keys for separate genera: Isorhipis [Muona, 1995]; Ischnomera [Kubisz, 2006]; Lamprodila [Byk, Mokrzycki, 2009]; Suphrodytes [Bergsten et al., 2012]; Leiopus [Zamoroka, Kapelyukh, 2012]; Cotaster [Diotti et al., 2015,2019]; Hydrobius [Fossen et al., 2016]; Hylesinus [Petrov, 2018].

\section{Results}

During examination and identification of the materials from the territory of Kaliningradskaya Oblast, a list of 30 most interesting (insufficiently known, sporadically distributed in the Baltic States and also several protected by law in the region ones) species was com- 
piled. Of these, 10 species of Coleoptera are recorded from Kaliningradskaya Oblast for the first time. These new species reports for the fauna are marked in the list with one asterisk (*). For all listed beetle species, additional brief information concerning the localities and data of observation, bionomy and distribution are provided.

\section{Carabidae Latreille, 1802}

\section{Oodes gracilis Villa et Villa, 1833}

Material. Baltiysk district, Mechnikov vicinity, $54^{\circ} 41^{\prime} 48^{\prime \prime} \mathrm{N}, 19^{\circ} 55^{\prime} 41^{\prime \prime} \mathrm{E}$, sandy beach of the Baltic Sea, 9.04.2018, 1 ex.

Comments. On the territory of the northern part of the former East Prussia, it was recorded [Bercio, Folwaczny, 1979] from Palmnicken [now Yantarny] only. The species is recorded in Sweden, Estonia, Latvia, and Lithuania [Silfverberg, 2010].

\section{Ophonus laticollis Mannerheim, 1825}

Material. Chernyakbovsk, 54 $38^{\prime} 32^{\prime \prime} \mathrm{N}, 21^{\circ} 49^{\prime} 34^{\prime \prime} \mathrm{E}$, on grass, bank of the river Angrapa, 19.07.2019, 1 ex.

Comments. On the territory of the northern part of the former East Prussia, it was seemingly not so rare and was reported [Bercio, Folwaczny, 1979] under the name «punctatulus Dft.» from: Friedland [Pravdinsk], Szillen [Zhilino in Neman district], Karalene [Zeleny Bor in Chernyakhovsk district] and Insterburg [Chernyakhovsk]. The species is widely distributed in the Baltic region and Fennoscandia and is recorded in all countries except Norway [Silfverberg, 2010].

Dytiscidae Leach, 1815

* Suphrodytes figuratus (Gyllenhal, 1826)

Material. Zelenogradskaya oblast, Sosnovka vicinity, $54^{\circ} 56^{\prime} 29^{\prime \prime} \mathrm{N}, 20^{\circ} 30^{\prime} 39^{\prime \prime} \mathrm{E}$, eutrophic drainage ditch with Lemna, meadow, 10.06.2000, 2 exx.; Nesterov district, $3 \mathrm{~km} \mathrm{E}$ Uvarovo, $54^{\circ} 23^{\prime} 23^{\prime \prime} \mathrm{N}, 22^{\circ} 42^{\prime} 40^{\prime \prime} \mathrm{E}$, forest pool, 11.07.2000, 2 exx.; Baltiysk district, the Baltic Spit, 54 $37^{\prime} 00^{\prime \prime} \mathrm{N}, 19^{\circ} 51^{\prime} 32^{\prime \prime} \mathrm{E}$ surf zone of the Baltic Sea, 23.04.2018, 1 ex.

Comments. This species has not been recorded from the territory of the former East Prussia or from the present-day Kaliningradskaya Oblast, because the separation of the sympatric similar European species S. dorsalis (Fabricius, 1787) and $S$. figuratus is comparatively recent event [Bergsten et al., 2012] and all earlier records cover both species under the name «dorsalis». The presence of both species on our territory could be supposed only in accordance with wide distribution of species and their ecology: the species «are broadly sympatric across the Palearctic and frequently even collected at the same locality» [Bergsten et al., 2012]. Thus, this is the first formal record of this species from the territory of Kaliningradskaya Oblast in confirming the occurrence of this second species, whereas true $S$. dorsalis has been reported earlier [i.e. Alekseev, Shapoval, 2019]. The habitat preference of $S$. figuratus in Kaliningradskaya Oblast seems to be is similar to that in Belgium [Scheers et al., 2014]: the species is connected with the shaded, enriched pools and ditches with a muddy bottom with a thick layer of decaying leaves.

Hydrophilidae Latreille, 1802

* Hydrobius rottenbergii Gerhardt, 1872

Material. Baltiysk district, Tanketino vicinity, $54^{\circ} 43^{\prime} 40^{\prime \prime} \mathrm{N}$, $19^{\circ} 56^{\prime} 48^{\prime \prime} \mathrm{E}$, surf zone of the Baltic Sea, 15.05.2019, 1 ex.

Comments. This species has not been recorded from the territory of the former East Prussia or Kaliningradskaya
Oblast, because the splitting of $H$. fuscipes (Linnaeus, 1758) into three species has published recently [Fossen et al., 2016]. H. rottenbergii is known in Norway, Sweden [Fossen et al., 2016], Germany, Poland, Belarus [Ryndevich, 2016], Latvia, and Russia [Ryndevich, 2017]. This is the first formal record of this species from the territory of Kaliningradskaya Oblast, whereas true $H$. fuscipes has been reported earlier [Alekseev, Shapoval, 2019] from the Curonian Spit.

Geotrupidae Latreille, 1806

Typhaeus typhoeus (Linnaeus, 1758)

Fig. 1.

Material. Baltiysk district, Khmelevka vicinity, $54^{\circ} 45^{\prime} 06^{\prime \prime} \mathrm{N}$, $19^{\circ} 57^{\prime} 30 " \mathrm{E}$, surf zone of the Baltic Sea, $+7{ }^{\circ} \mathrm{C}, 4.12 .2019$, female and male; ibidem, surf zone, $+8{ }^{\circ} \mathrm{C}, 18.12 .2019,2$ male exx.; ibidem, surf zone, $+4{ }^{\circ} \mathrm{C}, 2.01 .2020,2$ male exx.

Comments. The species was recently removed [Alekseev, 2018] from the regional check-list and from the regional and Russian fauna due to absence of any data from the region since the old German publication with the locality «Königsberg» [Lentz, 1879], as well as due to the species ecology and known distribution (reported trophic preference and coincidence of the distribution with the distribution range of a wild rabbit, i.e. westwards of the Wisła River in Poland). Evidence of December 2019 suggests that exclusion was wrong and too hasty: the species inhabits at least one coastal meadow with sandy soil along the Baltic Sea in the south-western part of the Sambian Peninsula (Kaliningradskaya Oblast, Russia). Six living specimens ( 1 female and 5 males) collected in the mild winter period of 2019-2020 indicate the presence of stable local population. The winter- and spring-active imago with the unusual for regional beetles flying time in December and January can additionally make «hidden» this spectacular species for collectors. The trophic connection with rabbit excrements should be considered optional for the species: the «Typhaeus meadow» can provide faeces of hare, dog, human, and perhaps wild boar and roe; the beetles consume the hare excrements in captivity. The rabbit don't occur in Kaliningradskaya Oblast, the influence of Atlantic climate on the distribution of minotaur beetle should be more significant. The climatic characteristics of Baltiysk district (where the species was sampled) are following: mean annual temperature $+7.5^{\circ} \mathrm{C}$; average January temperature $-2.5^{\circ} \mathrm{C}$; average July temperature $+17.5{ }^{\circ} \mathrm{C}$. These conditions are the most Atlantic influenced and belong to the mildest ones in winter time throughout Kaliningradskaya Oblast. The monitoring of the recently discovered population of Typhaeus typhoeus at its extreme eastern distribution edge is necessary; the species needs to be included in the regional Red Data Book. The peculiarities of biology of the beetle in the region need to be studied, but the main features would be similar with mentioned for the Netherlands [Brussaard, 1983].

\section{Scarabaeidae Latreille, 1802 Copris lunaris (Linnaeus, 1758)}

Fig. 2A.

Material. Zelenogradsk district, N Kostrovo, 54⒋'34" N, 2005'16"E, under horse excrements, pasture, 5.06.2019, 1 male.

Comments. The species is listed in the Red Data Book of Kaliningradskaya Oblast [Dedkov, Grishanov, 2010]; it occurs in the region at northern periphery of main distributional area, however can be locally encountered eastwards and northeastwards also in Lithuania and Latvia [Alekseev, 2018]. This is the second known actual locality of the species in the region. 

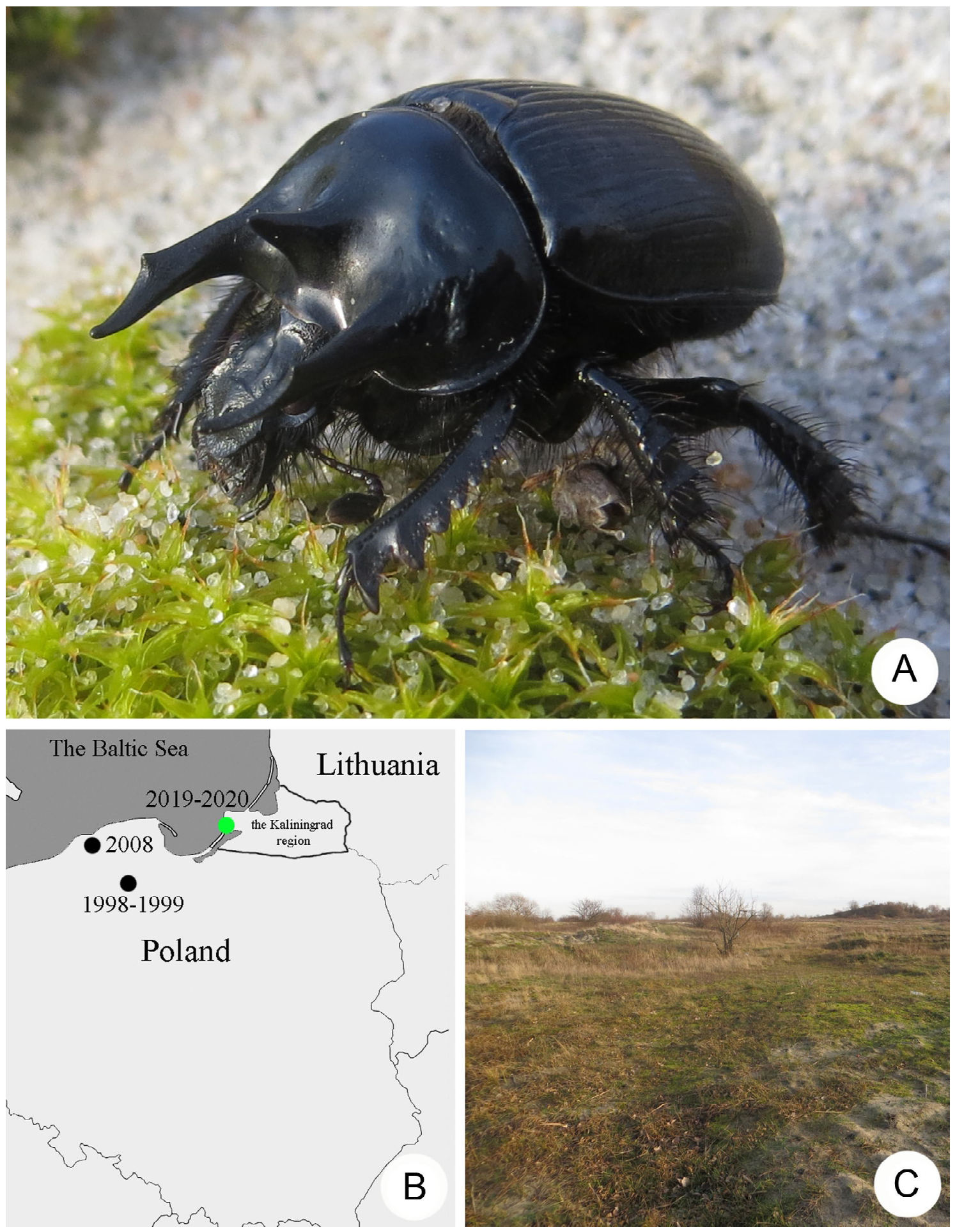

Fig. 1. A - Typhaeus typhoeus (L.), male; B - the map of the closest to Kaliningradskaya Oblast localities of the species in the northern Poland known from literature [Hetmacski et al., 2009; Byk, 2011]: black points and actual report from Russia, green point; C - habitat of T. typhoeus.

Fig. 1. A - Typhaeus typhoeus (L.), самец; В - карта ближайших к Калининградской области мест находок вида в северной Польше по митературным данным [Hetmacski et al., 2009; Byk, 2011]: черные точки и место сбора в России, зеленая точка; C - биотоп T. typhoeus. 


\section{Osmoderma barnabita Motschulsky, 1845}

Fig. 2B.

Material. W Kaliningrad, $54^{\circ} 44^{\prime} 30^{\prime \prime} \mathrm{N}, 20^{\circ} 24^{\prime} 25^{\prime \prime} \mathrm{E}, 14: 00$ a broad-leaved tree stand near the Fillipov Pond, oak with hollow in three meters above the ground, 29.06.2019, $1 \mathrm{ex}$. observed; ibidem, in the same place at 14:00, 25.07.2019, 1 ex. observed; ibidem, observed in the same place at 14:30, 16.08.2019, 1 ex.

Comments. The species is listed in the Red Data Book of Kaliningradskaya Oblast [Dedkov, Grishanov, 2010]. The mentioned observations add one new locality to known [Alekseev, 2018] regional distributional pattern. It is likely that the observed specimen was the same (in this case the lifespan of an adult beetle consisted at least 49 days). The diurnal schedule is curious and could be specific for habitat (i.e. dependent on illumination and temperature in the hollow) or specimen-specific.

\section{Gnorimus nobilis nobilis (Linnaeus, 1758)}

Fig. 2C-D.

Material. Svetlogorsk district, Primor'e, 54 56 46" N, $20^{\circ} 02^{\prime} 12^{\prime \prime} \mathrm{E}$, park and abandoned garden in settlement, on flowers, 7.06.2019, 4 exx. observed; Polessk district, NE Sosnovka, $54^{\circ} 50^{\prime} 15^{\prime \prime} \mathrm{N}, 21^{\circ} 21^{\prime} 44^{\prime \prime} \mathrm{E}$, road at the forest margin, on flowers, 12.06.2019, 8 exx. observed; Gvardeysk district,

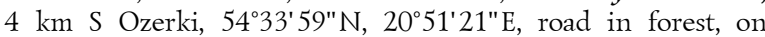
flowers, 18.06.2019, 4 exx., observed; Zelenogradsk district, $3 \mathrm{~km}$ W Ryabinovka, 54 $49^{\circ} 07^{\prime \prime} \mathrm{N}, 20^{\circ} 27^{\prime} 47^{\prime \prime} \mathrm{E}$, road in forest, on flowers, 21.06.2019, 3 exx. observed; Bagrationovsk district, Medovoe, $54^{\circ} 32^{\prime} 05^{\prime \prime} \mathrm{N}, 20^{\circ} 22^{\prime} 10^{\prime \prime} \mathrm{E}$, dead specimen on the road in settlement, 11.07.2019, 1 ex.

Comments. The species is listed in the Red Data Book of Kaliningradskaya Oblast [Dedkov, Grishanov, 2010]. The samplings and observations of the season-2019 add three new localities to known [Alekseev, 2018] distributional pattern in the region.

\section{Lycidae Laporte de Castelnau, 1836 \\ * Lopheros rubens (Gyllenhal, 1817)}

Fig. 2E.

Material. Kaliningrad, $54^{\circ} 43^{\prime} 26^{\prime \prime} \mathrm{N}, 20^{\circ} 29^{\prime} 30^{\prime \prime} \mathrm{E}$, territory of the Kaliningrad zoo, 11.05.2018, 1 ex.

Comments. The species is absent in the list of the beetles of the former East Prussia [Bercio, Folwaczny, 1979], perhaps it has been overlooked. The species is widely distributed in the Baltic region and Fennoscandia and is recorded in all countries except Denmark [Silfverberg, 2010]. This is the first registration of the species in Kaliningradskaya Oblast, but the actual habitat of the species is unknown. The reported specimen seems to have been accidentally introduced into Kaliningrad with timber.

\section{Eucnemidae Eschscholtz, 1829 \\ * Isorhipis marmottani Bonvouloir, 1871}

Material. Polessk district, Bogatovo vicinity, $54^{\circ} 50^{\prime} 45^{\prime \prime} \mathrm{N}$, $21^{\circ} 21^{\prime} 21^{\prime \prime} \mathrm{E}$, on standing dead ash-tree near road in mixed forest, 12.06.2019, 3 exx. females.

Comments. The species is absent in the list of the beetles of the former East Prussia [Bercio, Folwaczny, 1979], perhaps it has been overlooked or confused with congeneric I. melasoides (Laporte, 1835). The species is sporadically distributed in Europe and is reported in the Baltic region from Sweden, Norway, Estonia [Muona, 1995; Silfverberg, 2010], and Poland [i.e. Szołtys, Taszakowski, 2017].

\author{
Buprestidae Leach, 1815 \\ Lamprodila rutilans rutilans \\ (Fabricius, 1777) \\ Fig. 2F.
}

Material. Polessk district, Sosnovka vicinity, $54^{\circ} 49^{\prime} 45^{\prime \prime} \mathrm{N}$, $21^{\circ} 22^{\prime} 10^{\prime \prime} \mathrm{E}$, linden $\log$ on the margin of mixed forest, 26.06.2019, 1 ex.

Comments. On the territory of the northern part of the former East Prussia, it was recorded [Bercio, Folwaczny, 1979] from Königsberg [Kaliningrad] and Katharinenhof [Yamskoe in Bagrationovsk district]. The species has been mistakenly reported from Kaliningradskaya Oblast [Alekseev, Nikitsky, 2008], that specimen belongs to L. decipiens (see comment below). L. rutilans in Baltic region is known in Finland, Norway, Lithuania [Silfverberg, 2010], Poland [Byk, Mokrzycki, 2009; Oleksa et al., 2009]. This is the first actual record of the species in the Kaliningrad Region. Larvae develop under bark and in phloem of trunks and thick branches of old lindens. The species sporadically occurs in Kaliningradskaya Oblast and Lithuania at northern periphery of main distributional area.

\section{Lamprodila decipiens decipiens (Gebler, 1847)}

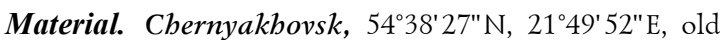
park, on foliage, 5.06.1993, 1 ex.

Comments. The specimen was misidentified by the author [Alekseev, Nikitsky, 2008] as «Ovalisia rutilans», but in fact belongs to $L$. decipiens. It is single known actual locality of this species in Kaliningradskaya Oblast. On the territory of the northern part of the former East Prussia, it was recorded [Bercio, Folwaczny, 1979] from Königsberg [Kaliningrad] only. The species is reported from Latvia [Silfverberg, 2010], and Poland [Byk, Mokrzycki, 2009], but should be more widely distributed in Baltic Region, despite everywhere is sporadic and rare. Larvae develop under bark of branches and trunks of willows, most frequently in Salix caprea.

\section{Poecilonota variolosa (Paykull, 1799)}

Fig. 3A.

Material. Polessk district, Sosnovka vicinity, $54^{\circ} 49^{\prime} 45^{\prime \prime} \mathrm{N}$, $21^{\circ} 22^{\prime} 10^{\prime \prime} \mathrm{E}$, aspen log on the margin of mixed forest, 26.06.2019, 1 ex.

Comments. On the territory of the northern part of the former East Prussia, it was reported [Bercio, Folwaczny, 1979] from Hirschau [Kolomenskoe in Zelenogradsk district], Königsberg [Kaliningrad], Wehlau [Znamensk], Insterburg [Chernyakhovsk]. The species is widely distributed in the Baltic region and Fennoscandia and is recorded in all countries except Denmark [Silfverberg, 2010]. This is the first actual record in Kaliningradskaya Oblast. The species is sporadic and associated with old aspen trees.

\section{Dicerca alni (Fischer von Waldheim, 1824) Fig. 3B.}

Material. Gvardeysk district, $3 \mathrm{~km} \mathrm{~S}$ Ozerki, 543' $33^{\prime \prime} \mathrm{N}$, $20^{\circ} 52^{\prime} 10^{\prime \prime} \mathrm{E}$, on fresh log of Populus tremula, mixed forest edge, 18.06.2019, 2 exx

Comments. Faunal information on this species in the territory of Kaliningradskaya Oblast and adjacent territories was presented earlier [Alekseev, Bukejs, 2017]. This is the third actual locality of the species in the region, where the species is sporadic but apparently the most common species of the genus. 

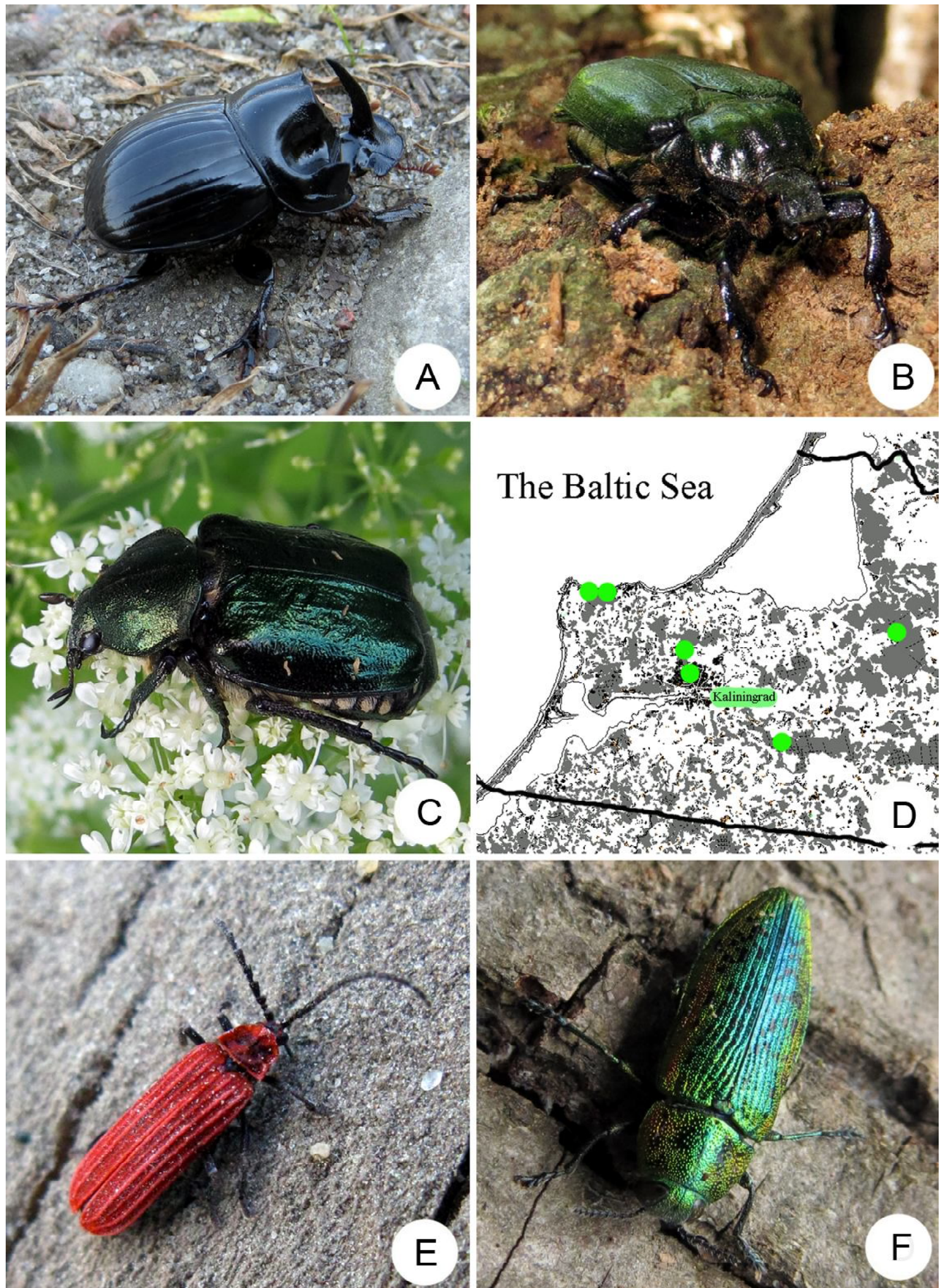

Fig. 2. A - Copris lunaris (L.), male; B - Osmoderma barnabita Motsch.; C - Gnorimus nobilis nobilis (L.); D - the map of the known actual localities of G. nobilis in the western part of Kaliningradskaya Oblast; E - Lopheros rubens (Gyll.); F Lamprodila rutilans rutilans (F.).

Fig. 2. A - Copris lunaris (L.), самец; B - Osmoderma barnabita Motsch.; C - Gnorimus nobilis nobilis (L.); D - карта известных современных мест обитания G. nobilis в западной части Калининградской области; Е - Lopheros rubens (Gyll.); F - Lamprodila rutilans rutilans (F.). 


\section{* Trachys fragariae Brisout de Barneville, 1874}

Material. Baltiysk district, Tanketino vicinity, $54^{\circ} 43^{\prime} 54^{\prime \prime} \mathrm{N}, 19^{\circ} 57^{\prime} 09^{\prime \prime} \mathrm{E}$, sandy pit, dry coastal meadow near the Baltic Sea, 15.05.2019, 1 ex.; $1 \mathrm{~km}$ E Chernyakhovsk, $54^{\circ} 38^{\prime} 57^{\prime \prime} \mathrm{N}, 21^{\circ} 51^{\prime} 11^{\prime \prime} \mathrm{E}$, in sandy pit, dry meadow near the Angrapa river, 30.04.2018, 2 exx.

Comments. The species is absent in the list of the beetles of the former East Prussia [Bercio, Folwaczny, 1979], perhaps it has been overlooked or absent before the second half of the 20th century. The species is reported in the Baltic region from Lithuania [Silfverberg, 2010; Tamutis et al., 2011] and Poland. The olygophagous species is connected with the Fragaria and Potentilla spp. The species probably extends the distribution range northwards nowadays and occurs in the intrazonal xeric habitats like coastal meadows and river valleys in Kaliningradskaya Oblast at northern periphery of main distributional area.

\section{Agrilus pratensis (Ratzeburg, 1837)}

Material. Bagrationovsk district, Sosnovka vicinity, $54^{\circ} 33^{\prime} 45^{\prime \prime} \mathrm{N}, 20^{\circ} 11^{\prime} 45^{\prime \prime} \mathrm{E}$, meadow, on young aspen, 25.06.2019, 2 exx.

Comments. On the territory of the northern part of the former East Prussia, it was reported [Bercio, Folwaczny, 1979] from Löwenhagen [Komsomol'sk in Gvardeysk district] with question mark only. The species is widely distributed in the Baltic region and Fennoscandia and is recorded in all countries except Denmark [Silfverberg, 2010]. This is the first actual record in Kaliningradskaya Oblast. The species is associated with young aspen trees.

Cleridae Latreille, 1802

Trichodes apiarius (Linnaeus, 1758)

$$
\text { Fig. 3C. }
$$

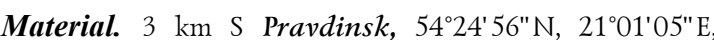
roadside near mixed forest, on flowers, 08.06.2019, 2 exx.;

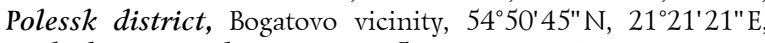
roadside in settlement, on flowers, 12.06.2019, 2 exx.; Bagrationovsk district, $2 \mathrm{~km}$ W Kamenka, 54⒉ $26^{\prime} 3^{\prime \prime} \mathrm{N}$, $20^{\circ} 24^{\prime} 26 " \mathrm{E}$, road in mixed forest, on flowers, 15.06.2019, 1 ex. observed; Gvardeysk district, 4 km S Ozerki, 54 34'27" N, $20^{\circ} 55^{\prime} 53^{\prime \prime} \mathrm{E}$, roadside in mixed forest, on flowers, 18.06.2019, 1 ex., observed.

Comments. The species is distributed in the Eastern Baltic region (but absent in Fennoscandia) and is recorded as native in Estonia, Latvia and Lithuania [Silfverberg, 2010]. On the territory of the former East Prussia, it was reported [Bercio, Folwaczny, 1979] from Insterburg [Chernyakhovsk] and the present-day northern Poland. The beetle seems to be wide-distributed in Kaliningradskaya Oblast, but the not long lifespan of imago and comparatively rare presence of apiary in the region make the beetle infrequent. The localities presented herein are all known at the moment actual records of the species in the region.

Erotylidae Latreille, 1802

\section{Combocerus glaber (Schaller, 1783)}

Material. Bagrationovsk district, $2 \mathrm{~km} \mathrm{~W}$ Novomoskovskoe, $54^{\circ} 34^{\prime} 0.6^{\prime \prime} \mathrm{N}, 20^{\circ} 11^{\prime} 57^{\prime \prime} \mathrm{E}$, pitfall trap on the dry meadow with Sarathamnus scoparius, 27.0308.05.2018, 1 ex.

Comments. The species is rare but widely distributed in the Baltic region and Fennoscandia and is recorded in all countries [Silfverberg, 2010], as well as in Belarus [Tsinkevich, 2005] and Poland [Ruta et al., 2011]. It is «one of the rarest Central European erotyline species» [Ruta et al., 2011], associated with xerothermic meadows. The former documented record of the species on the territory of the northern part of the former East Prussia was taken in Königsberg [Kaliningrad] almost 140 years ago, namely in the city part Glacis at 03.06.1880 [Bercio, Folwaczny, 1979]. This is the first actual record of the species in Kaliningradskaya Oblast.

Oedemeridae Latreille, 1810

* Ischnomera cyanea (Fabricius, 1792)

Fig. 3D.

Material. Pravdinsk, 54 $26^{\prime} 33^{\prime \prime} \mathrm{N}, 21^{\circ} 01^{\prime} 34^{\prime \prime} \mathrm{E}$, on an old living oak, park in the city, 08.06.2019, 1 ex.

Comments. The species is reported from Sweden, Denmark [Silfverberg, 2010] and Lithuania [Ferenca et al., 2016]. It is rare but wide-distributed in Poland [Kubisz, 2006]. The species is included in the list of the beetles of the former East Prussia [Bercio, Folwaczny, 1979] as «Ischnomera coerulea L. (cyanea F.)» with note "seldom» and without precise localities. The earlier synonymized I. coerulea and I. cyanea are considered different species nowadays, thus such old data from German catalogue is unclear in regard to taxon and its distribution. The locality presented herein is first record of the species in Kaliningradskaya Oblast. The species occurs in Kaliningradskaya Oblast and Lithuania at northern periphery of main distributional area.

Tenebrionidae Latreille, 1802

* Phaleria cadaverina cadaverina

(Fabricius, 1792)

Fig. $4 \mathrm{~A}-\mathrm{C}$.

Material. Zelenogradsk district, $3 \mathrm{~km} \mathrm{SW} \mathrm{Povarovka,}$ $54^{\circ} 48^{\prime} 28^{\prime \prime} \mathrm{N} 19^{\circ} 57^{\prime} 38^{\prime \prime} \mathrm{E}$, under dry crust of alga on the sandy beach, the Baltic Sea coast, 21.05.2018, 3 exx.

Comments. On the territory of the former East Prussia, the species was reported [Bercio, Folwaczny, 1979] from Zoppot (Sopot in Poland) with question mark. According to Silfverberg [2010], this halophilous species is reported from Sweden and Denmark. Phaleria was recently recorded from Poland for the first time [Gabriš, 2013; Tsinkevich et al., 2013; Aleksandrowicz, 2019]. The data presented here are the first confirmed record of the species in Russia. The specimens perhaps belong to the populations of the leading edge of main distribution area occupying intrazonal sandy beaches of the Atlantic coasts of Europe. An eastward shift of the leading edge in the southern Baltic area could be supposed and indicated by the newest findings in Poland and Kaliningradskaya Oblast. On the other hand it seems that Phaleria requires sandy beaches with a minimum of recreational activities [Gabriš, 2013] and maximum of nondisturbed sand for larval development. This fact can explain the sporadical and «hidden» occurrence of the species along the southern Baltic Sea coasts. Anyway, the monitoring of the recently discovered population of Phaleria cadaverina at its extreme eastern distribution edge is necessary and the species probably needs to be included in the regional Red Data Book.

\section{Pentaphyllus testaceus (Hellwig, 1792)}

Material. W Kaliningrad, 544ㄴ $30^{\prime \prime} \mathrm{N}, 20^{\circ} 24^{\prime} 25^{\prime \prime} \mathrm{E}$, pitfall trap, hollow oak with Laetiporus sulpbureus, broad-leaved tree stand near the Fillipov Pond, 7-26.05.2019, 2 exx.

Comments. Faunal information on this species in the territory of Kaliningradskaya Oblast and adjacent territories was presented earlier [Alekseev et al., 2012]. This is the second, actual locality of the species in the region. 

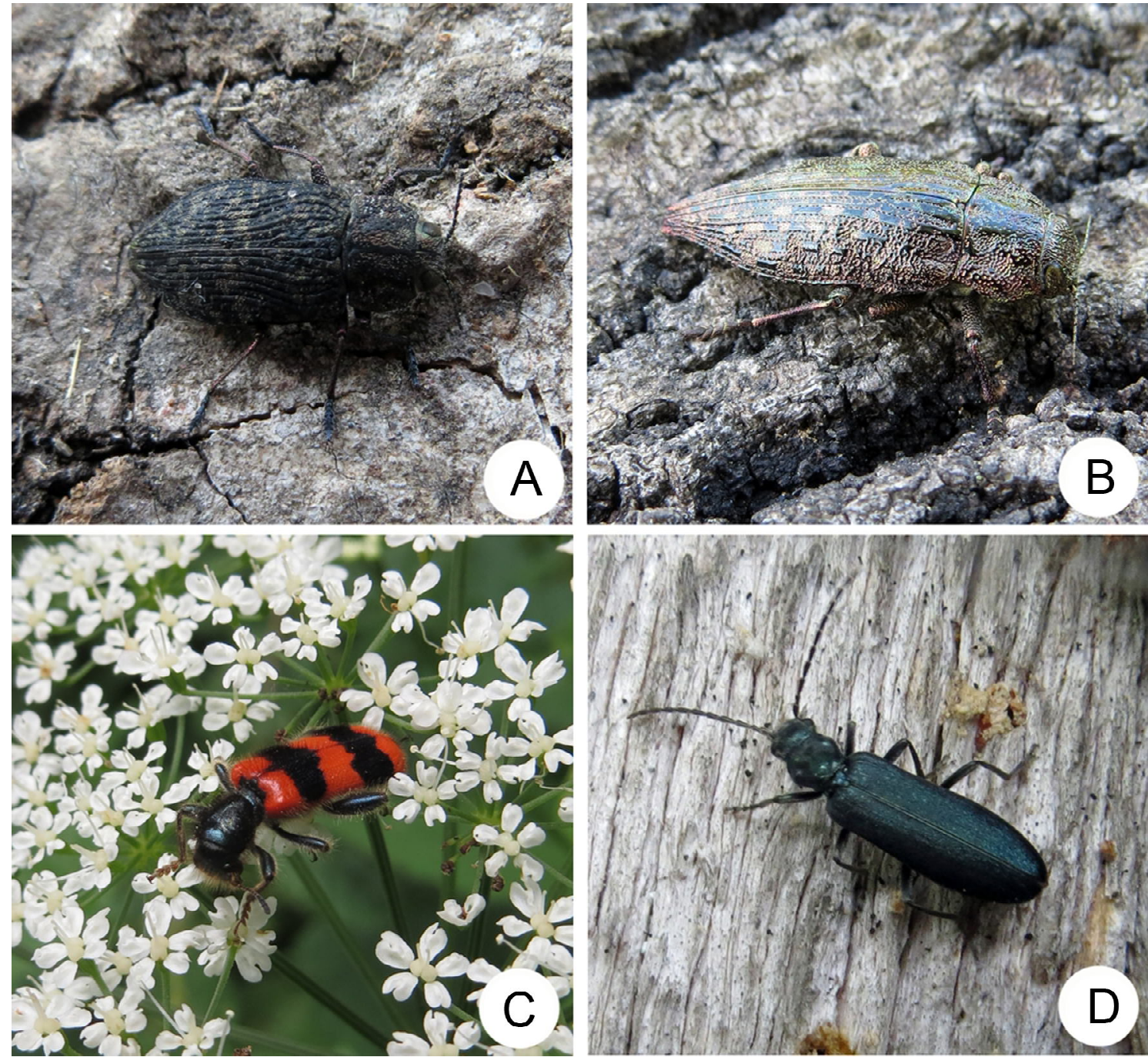

Fig. 3. A - Poecilonota variolosa (Payk.); B - Dicerca alni (Fisch.Waldh.); C - Trichodes apiarius (L.); D - Ischnomera cyanea (F.)

Fig. 3. A - Poecilonota variolosa (Payk.); B - Dicerca alni (Fisch.Waldh.); C - Trichodes apiarius (L.); D - Ischnomera cyanea (F.)

Cerambycidae Latreille, 1802

Prionus coriarius (Linnaeus, 1767)

Fig. 5A-B.

Material. W Kaliningrad, 544ㄴ $34^{\prime \prime}$ N, $20^{\circ} 24^{\prime} 25^{\prime \prime} \mathrm{E}$, pitfall trap, hollow oak, broad-leaved tree stand near the Fillipov Pond, 16.08.2019, 1 ex. observed.

Comments. Faunal information on this species in the territory of Kaliningradskaya Oblast and adjacent territories was presented earlier [i.e. Alekseev, Bukejs, 2017]. It is new locality of the listed in the Red Data Book of Kaliningradskaya Oblast species.

\section{Anaglyptus mysticus (Linnaeus, 1758)}

Fig. $5 \mathrm{C}-\mathrm{D}$

Material. Svetlogorsk district, Primor'e, 54 56'46"N, $20^{\circ} 02^{\prime} 12 \mathrm{E} \mathrm{E}$, abandoned garden in settlement, on foliage, 7.06.2019, 1 ex.

Comments. The species occurs in Kaliningradskaya Oblast at northeastern periphery of main distributional area, however can be locally encountered eastwards (in western Belarus) and northwards (Latvia). This is fourth known actual locality of the species in Kaliningradskaya Oblast and first registration of the comparatively rare greyish color form A. mysticus var. albofasciatus (DeGeer, 1775).

\section{Chlorophorus herbsti (Brahm, 1790) Fig. 5E.}

Material. Polessk district, Sosnovka vicinity, 54 49'45"N, $21^{\circ} 22^{\prime} 10^{\prime \prime} \mathrm{E}$, margin of mixed forest, sweeping, 12.06.2019, 1 ex.

Comments. According to Silfverberg [2010], this rare species is reported from Finland, Sweden, Estonia, Latvia and Lithuania. On the territory of the former East Prussia, the species was reported [Bercio, Folwaczny, 1979] from Blaustein [Dolny Siniec in Poland] only. There was only one found of the beetle in Kaliningradskaya Oblast [Alekseev, 2007], the data presented here are the second record of the species.

* Anaesthetis testacea (Fabricius, 1781)

Fig. $5 \mathrm{~F}$.

Material. Bagrationovsk district, $3 \mathrm{~km} \mathrm{SW}$ Novomoskovskoe, $54^{\circ} 33^{\prime} 42^{\prime \prime} \mathrm{N}, 20^{\circ} 12^{\prime} 7^{\prime \prime} \mathrm{E}$, forest edge, sweeping on bushes and young trees, 25.06.2019, 1 ex. 

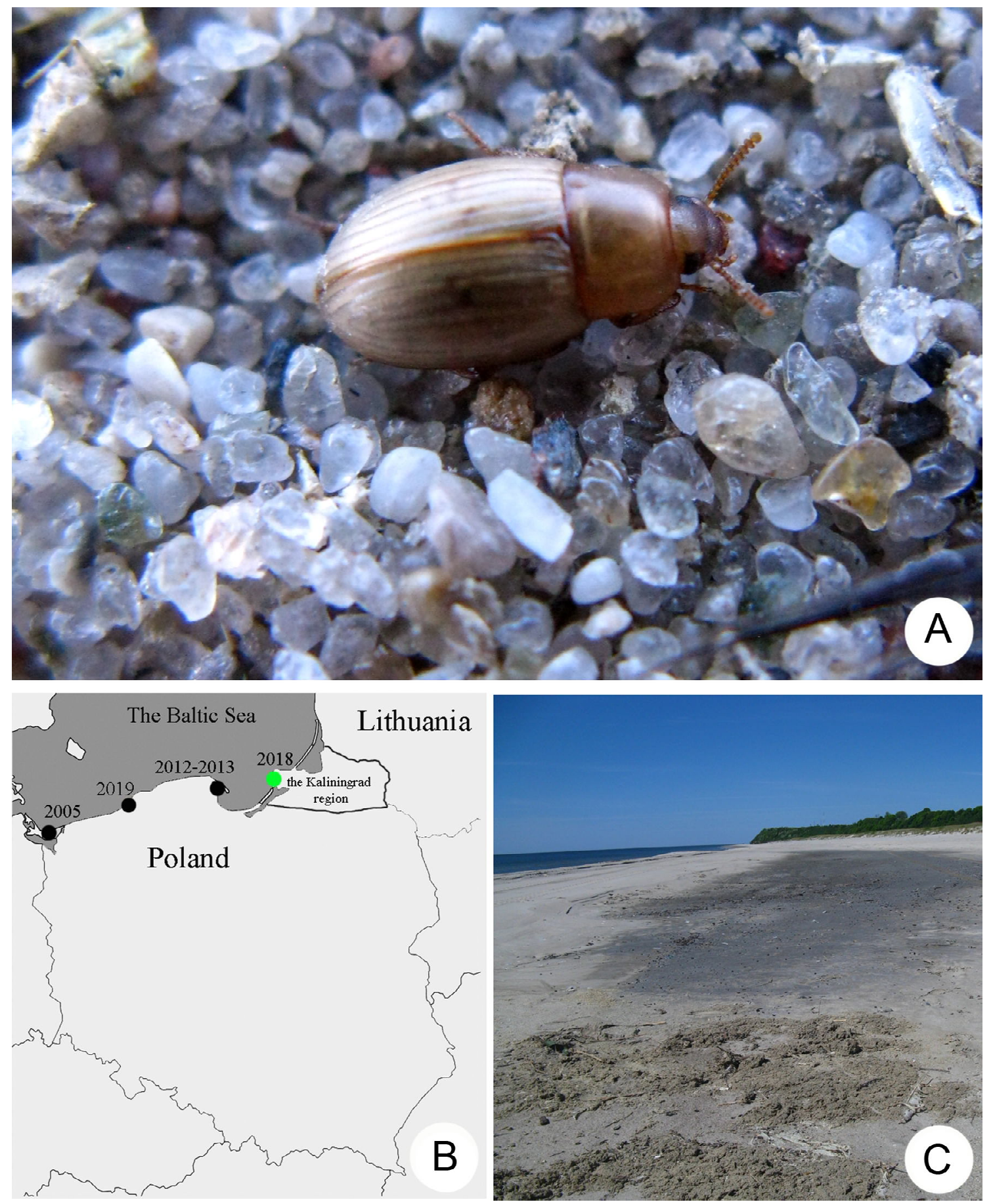

Fig. 4. A - Phaleria cadaverina cadaverina (F.); B - the map of the closest to Kaliningradskaya Oblast species localities in the northern Poland known from literature [Gabriš, 2013; Tsinkevich et al., 2013; Aleksandrowicz, 2019] (black points) and first report from Russia (green point); $\mathrm{C}-$ habitat of $\mathrm{Ph}$. cadaverina.

Fig. 4. A - Phaleria cadaverina cadaverina (F.); В - карта ближайших к Калининградской области мест регистрации вида в северной Польше по митературным данным [Gabris, 2013; Tsinkevich et al., 2013; Aleksandrowicz, 2019] (черные точки) и место первой находки вида в России (зелёная точка); С - биотоп Pb. cadaverina. 

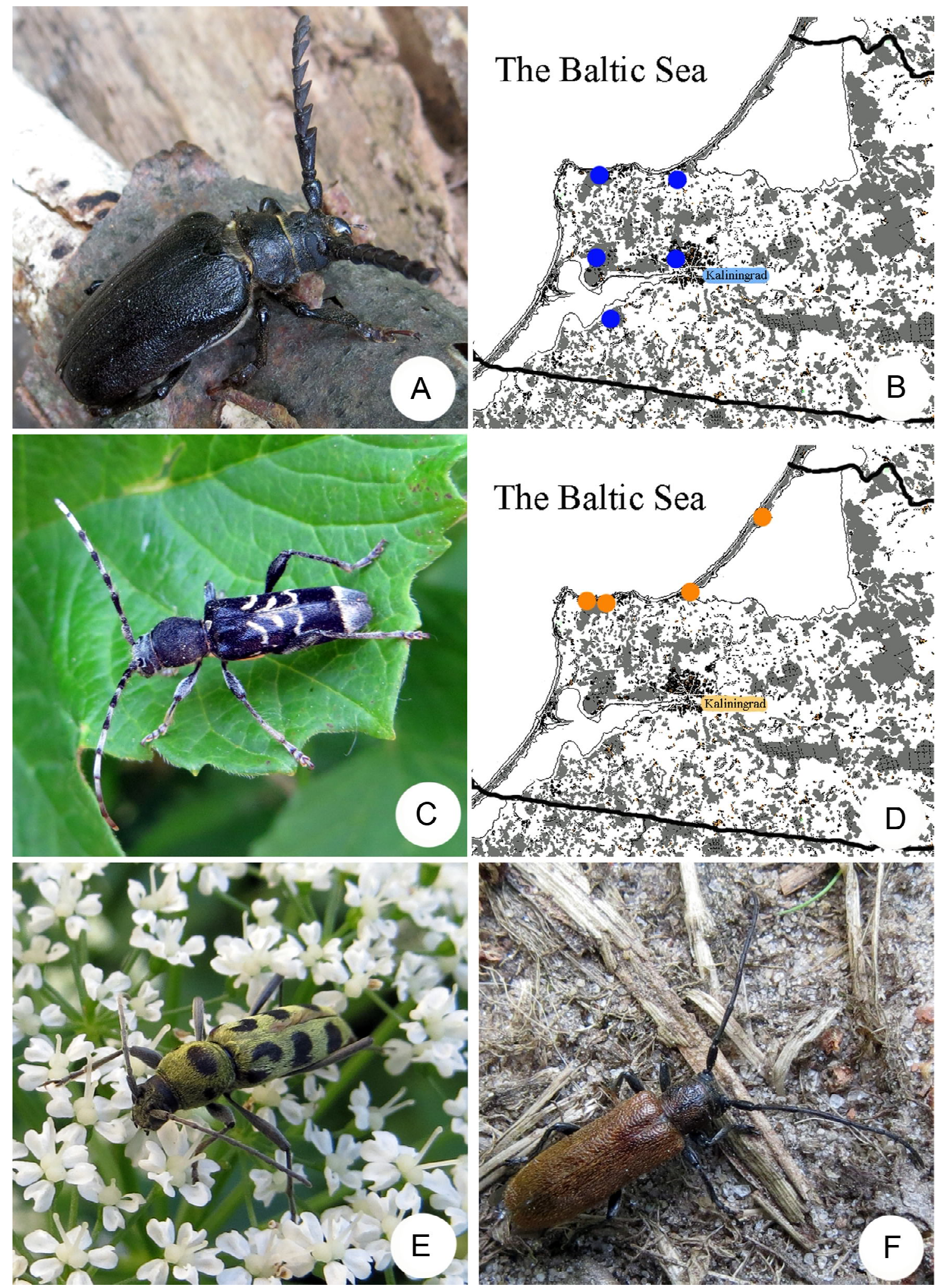

Fig. 5. A - Prionus coriarius (L.); B - the map of the known actual localities of P. coriarius in the western part of Kaliningradskaya Oblast; C - Anaglyptus mysticus var. albofasciatus (DeGeer, 1775); D - the map of the known actual localities of A. mysticus (L.) in the western part of Kaliningradsaya Oblast; E - Chlorophorus herbsti (Brahm); F - Anaesthetis testacea (F.).

Fig. 5. A - Prionus coriarius (L.); В - карта известных современных мест обитания P. coriarius в западной части Калининградской области; С - Anaglyptus mysticus var. albofasciatus (DeGeer, 1775); D - карта известных современных мест обитания A. mysticus (L.) в западной части Калининградской области; E - Chlorophorus herbsti (Brahm); F - Anaesthetis testacea (F.) 
Comments. The species is known in the Baltic region and Fennoscandia from Sweden, Estonia and Latvia [Silfverberg, 2010]. It is also known from NE Poland [i.e. Bercio, Folwaczny, 1979]. This is the first report of the species from Kaliningradskaya Oblast.

\section{* Leiopus femoratus Fairmaire, 1859 Fig. 6A-B.}

Material. Kaliningrad, $54^{\circ} 43^{\prime} 43^{\prime \prime} \mathrm{N}, 20^{\circ} 25^{\prime} 38^{\prime \prime} \mathrm{E}$, roadside, suburbs, 16.06.2019, 1 ex.

Comments. The species is absent in the list of the beetles of the former East Prussia [Bercio, Folwaczny, 1979] and apparently was absent in the regional fauna before the XXI century. The species is known in the Baltic region from Lithuania only [Ferenca, 2004; Silfverberg, 2010]. In the Central Europa this southern species was registered recently: in 2004 in western Gemany and in 2007 in Luxembourg [Gerend, Meyer, 2007]; in 1997 it was found in Central Ukraine and in 2004 in western Ukraine [Zamoroka, Kapelyukh, 2012] with all known localities situated south of $50^{\circ}$ north latitude in this country; in 2007-2008 in the Netherlands [Teunissen, Jansen, 2009]; in 2009 in Hungary [Hegyessy, Kutasi, 2010]. The history of the northward spread of the beetle in Europe is not adequately documented and clear (apparently, the species spreads in lowlands and hugs the mountainous territories). The reasons of invasion can be hypothesized only. The locality in Kaliningrad (Russia) is one of the northernmost known points of this Euro-Turanian thermophilic species at present.

\section{Rhamnusium bicolor bicolor (Schrank, 1781) Fig. 6C-D.}

Material. Kaliningrad, $54^{\circ} 43^{\prime} 27^{\prime \prime} \mathrm{N}, 20^{\circ} 30^{\prime} 14^{\prime \prime} \mathrm{E}$, roadside under maples, 4.06.2018, 1 ex.; 3 km SW Pravdinsk, $54^{\circ} 25^{\prime} 01^{\prime \prime} \mathrm{N}, 21^{\circ} 00^{\prime} 53^{\prime \prime} \mathrm{E}$, on the dead standing Populus nigra near lake, 8.06.2019, 1 ex.; Bagrationovsk district, $1 \mathrm{~km} \mathrm{E}$ Kornevo, $5^{\circ} 26^{\prime} 51^{\prime \prime} \mathrm{N}, 20^{\circ} 19^{\prime} 30^{\prime \prime} \mathrm{E}$, in hollow of the old Acer platanoides, 15.06.2019, 1 ex.

Comments. On the territory of the northern part of the former East Prussia, it was reported [Bercio, Folwaczny, 1979] from Arnau [Rodniki in Gur'evsk district] and Insterburg [Chernyakhovsk]. According to Silfverberg [2010], this sporadically distributed species is reported as native from Finland, Estonia, Latvia and Lithuania. The localities presented herein are all known at the moment actual records of the species in Kaliningradskaya Oblast. The beetle is associated with the dead wood of the standing poplars and maples.

Curculionidae Latreille, 1802

Hylesinus toranio (D’Anthoine, 1788)

=oleiperda Fabricius, 1792.

Material. Kaliningrad, 5442' 52" N, 2026'12.3"E, flying, 11.07.2019, 1 ex.

Comments. On the territory of the northern part of the former East Prussia, the species was reported [Vorbringer, 1902; Bercio, Folwaczny, 1979] from Warnicken [Lesnoe in Svetlogorsk district], Königsberg Glacis, and Königsberg Plantage [Kaliningrad]. According to Silfverberg [2010], this sporadically distributed species is reported from Sweden, Norway, Denmark, and Latvia. This is the first actual report of the species from Kaliningradskaya Oblast.

\section{* Cotaster cf. cuneipennis (Aubé, 1850)} Fig. 6E-F.

Material. Svetlogorsk district, Otradnoe, 5456'39"N, $20^{\circ} 06^{\prime} 59^{\prime \prime} \mathrm{E}$, pitfall trap near Alnus glutinosa, forested cliff, the
Baltic Sea coast, 2.06-2.07.2019, 10 exx.; ibidem, 2.0710.07.2019, 1 ex.; ibidem, 7.08-4.09.2019, 1 ex.

Comments. On the territory of the former East Prussia [Bercio, Folwaczny, 1979] the beetle under name «Cotaster uncipes Boh.» was reported from Georgenswalde [Otradnoe in Svetlogorsk district] in 07.1860 and Warnicken [Lesnoe in Svetlogorsk district]. The focused pitfall sampling in 2019 resulted in dozen specimens of Cotaster, previously identified as belonging to $C$. cuneipennis. It is not doubtful that C. cuneipennis and C. speziai Diotti, Pesarini et Caldara, 2015 are two taxa very closely related species and their identification is very difficult [Diotti et al., 2015, 2019]. The specimens from Kaliningradskaya Oblast possess the scales of the elytral interstriae thin, non-spatulate, subrectangular to slightly enlarged from base to apex. The true identity of species recorded from the region requires verification by specialists and comparison with the type-material. Therefore, although presenting the first actual finding of Cotaster in Kaliningradskaya Oblast is justified, the identification of specimens must be treated as previous. The nearest localities of Cotaster sp. in Europe are known in the southern Poland and in the northern Germany (Schleswig-Holstein), the isolated occurrence in Kaliningradskaya Oblast is the northeastern known one.

\section{Bothrynoderes affinis (Schrank, 1781)}

Material.Zelenogradsk district, Okunevo vicinity, $54^{\circ} 49^{\prime} 34^{\prime \prime} \mathrm{N}, 19^{\circ} 57^{\prime} 04^{\prime \prime} \mathrm{E}$, sandy beach of the Baltic Sea, 30.05.2019, 2 exx.

Comments. On the territory of the northern part of the former East Prussia, the species was reported under name «Chromoderus fasciatus» [Bercio, Folwaczny, 1979] from Königsberg [Kaliningrad] only. The species is widely distributed in the Northern Europe and is recorded in all countries [Silfverberg, 2010]. This is the first actual report of the species from Kaliningradskaya Oblast.

Ten species (belonging to 9 families) are registered in the studied area for the first time, other 20 species were considered to be worth considering. The reported findings could be divided into following groups and subgroups:

1. The species with non-stable distribution ranges:

1.1. The invasive species with native area situated far from Kaliningradskaya Oblast and noticeable range expansion in the last decade (one species: Leiopus femoratus);

1.2. The species with oscillations of range boundaries, mainly intrazonal species dispersed along the Baltic Sea coasts and river valleys from south and west (two species: Phaleria cadaverina and Trachys fragariae, as well as Zabrus tenebrioides (Goeze, 1777) [Alekseev, Bukejs, 2017]);

2. The species with the more or less stable distribution ranges:

2.1. Native hidden species with short-lived imago and/or local habitats within main distribution area or on the periphery of their range (four regionally new species: Lopheros rubens, Isorhipis marmottani, Ischnomera cyanea, Anaesthetis testacea, and all 20 regionally not new species);

2.2. Native species not registered in the region due to modern taxonomical studies and recent splitting of species by researches (three species: Suphrodytes fig- 

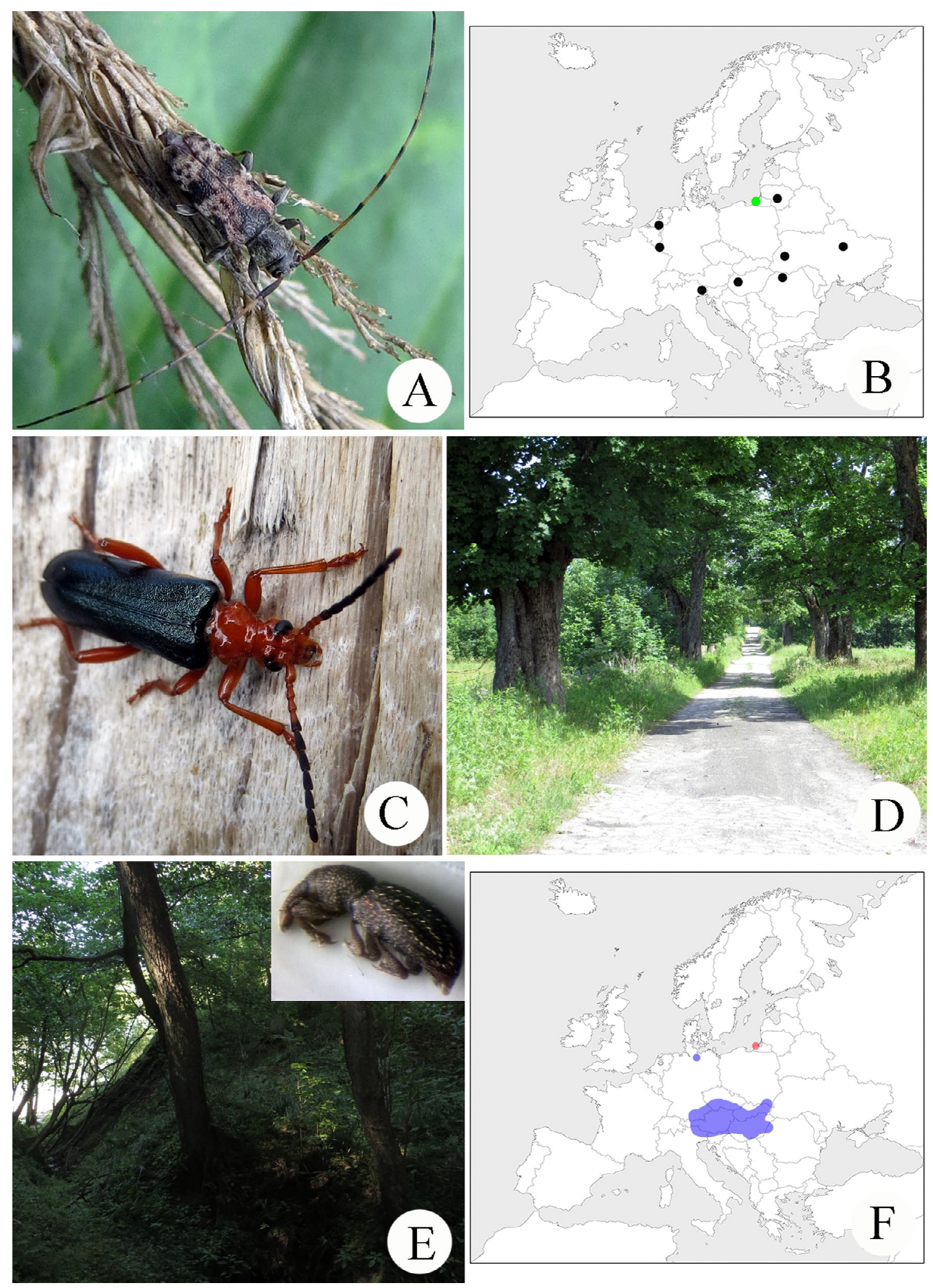
uratus, Hydrobius rottenbergii, and Cotaster cf. cuneipennis).

The given subdivision is not always formally logical or completely indisputable: Isorhipis marmottani and Ischnomera cyanea can be possibly treated as subgroup 2.2 too; the attribution of the species to the group 1.2 or 2.1 is ever under question. The composition of the group 2.1 is also a little subjective: the distribution of native beetles (e.g. such as Typhaeus typhoeus or Anaglyptus mysticus) in the region can be favored by the maritime or other «intrazonal» microclimatic conditions and belong to the group 1.2 in the long historical perspective. Anyways, the current coverage of the faunistic recording in the region is not amply and sufficient for any analyze of the details of the range boundaries of the beetles species. Several taxa with their northern, eastern or north-eastern distribution limit in Kaliningradskaya Oblast are registered, but the faunistic researches should be continued and may yield interesting additional results in future.

\section{Acknowledgements}

I thank Viktor V. Alekseev, Anastasia V. Alekseeva (Kaliningrad), and Irina I. Alekseeva (Chernyakhovsk) for accompanying me in field samplings and for enthusiastic providing me with all detected small beetles. I am grateful to Roland Suikat (Preez, Germany) for encouraging me to search $\mathrm{Co}$ taster on the coasts of the Sambian peninsula. I am very thankful also to two anonymous referees for their helpful comments on an earlier version of the manuscript.

\section{References}

Aleksandrowicz O. 2019. [New data on the distribution of Phaleria cadaverina cadaverina (Fabricius, 1792) (Coleoptera, Tenebrionidae) on the south coast of the Baltic sea (middle polish Pomeranian)] // Prirodnicha nauka y osvita: suchasniy stan i perspektivi rozvitku: materiali II mezhdunarodnoi naukovo-praktichnoi konferentsii. Kharkiv: KhNPU. P.2932. [In Russian]

Alekseev V.I. 2007. Longhorn beetles (Coleoptera: Cerambycidae) of Kaliningrad region // Acta Biologica Universitatis Daugavpiliensis. Vol.7. No.1. P.37-62.

Alekseev V.I. 2018. Scarabaeoidea (Insecta: Coleoptera) of the Kaliningrad Region (Russia): the commented actual checklist, assessment of rarity and notes to regional protection // Acta Biologica Universitatis Daugavpiliensis. Vol.18. No.2. P. $111-152$.

Alekseev V.I., Bukejs A. 2017. Contributions to the knowledge of beetles (Insecta: Coleoptera) in the Kaliningrad Region. 6 // Zoology and Ecology. Vol.27. No.3-4. P.261-268.
Alekseev V.I., Bukejs A., Balalaikins M. 2012. Contributions to the knowledge of beetles (Insecta: Coleoptera) in the Kaliningrad region. 3 // Zoology and Ecology. Vol.22. No.2. P.99-110.

Alekseev V.I., Nikitsky N.B. 2008. Rare and new for the fauna of the Baltic States beetles (Coleoptera) from the Kaliningrad region // Acta Zoologica Lithuanica, Vol.18. No.4. P.254259.

Alekseev V.I., Shapoval A.P. 2019. Beetles (Insecta, Coleoptera), sampled with use of light trap on the Curonian Spit: the materials of the sixth season // Acta Biologica Sibirica. Vol.5. No.2. P.68-82. [In Russian]

Bercio H., Folwaczny B. 1979. Verzeichnis der Käfer Preussens. Fulda: Parzeller \& Co. 369 S.

Bergsten J., Brilmyer G., Crampton-Platt A., Nilsson A.N. 2012. Sympatry and colour variation disguised well-differentiated sister species: Suphrodytes revised with integrative taxonomy including $5 \mathrm{kbp}$ of housekeeping genes (Coleoptera: Dytiscidae). // DNA Barcodes. Vol.1. P.1-18.

Brussaard L. 1983. Reproductive behaviour and development of the dung beetle Typhaeus typhoeus (Coleoptera, Geotrupidae) // Tijdschrift voor Entomologie. D.126. AFL.10. S.203231.

Byk A. 2011. Abundance and composition of Geotrupidae (Coleoptera: Scarabaeoidea) in the developmental cycle of pine stands in $\mathrm{Cz}^{3}$ uchów Forest (NW Poland) // Baltic Journal of Coleopterology. Vol.11. No.2. P.171-186.

Byk A., Mokrzycki T. 2009. Lamprodila mirifica (Mulsant, 1855) (Buprestidae: Chrysochroinae: Poecilonotini) - new for the fauna of Poland. Key to the identification of Polish species of the genus Lamprodila Motschulsky, 1860 // Fragmenta Faunistica. Vol.52. No.2. P.91-97.

Dedkov V. P., Grishanov G.V. (Eds.) 2010. Red Data Book of Kaliningrad Region. Kaliningrad: RGU im. Kanta. 334 p. [In Russian].

Diotti L., Pesarini C., Caldara R. 2015. Revisione sistematica del genere Cotaster Motschulsky: nuove sinonimie e descrizione di due nuove specie (Coleoptera, Curculionidae) // Giornale italiano di Entomologia. Vol.14. No.60. P.223-240.

Diotti L., Caldara R., Krátkı J. 2019. On the distributions of Cotaster cuneipennis (Aubé, 1850) and C. speziai Diotti et al., 2015 (Coleoptera: Curculionidae: Cossoninae). // Giornale italiano di Entomologia. Vol.15. No.64. P.241-246.

Ferenca R. 2004. New and rare for Lithuania beetle (Coleoptera) species registered in 1978-2004 // Naujos ir retos Lietuvos vabzd iu rušys. T.16. P.11-22.

Ferenca R., Tamutis V., Inokaitis V., Martinaitis K. 2016. Data on beetle (Coleoptera) species new to Lithuanian fauna // Naujos ir retos Lietuvos vabzd iu rušys. T.28. P. 21-31.

Fossen E.I., Ekrem T., Nilsson A.N., Bergsten J. 2016. Species delimitation in northern European water scavenger beetles of the genus Hydrobius (Coleoptera, Hydrophilidae) // ZooKeys. Vol.564. P.71-120.

Freude H., Harde K.W., Lohse G.A. 1965-1989. Die Käfer Mitteleuropas. Bd.1-15. Krefeld: Goecke \& Evers.

Freude H., Harde K.W., Lohse G.A., Klausnitzer B. 2004. Die Käfer Mitteleuropas. Bd: 2. Carabidae. München: Elsevier GmbH-Spectrum, $521 \mathrm{~S}$

Fig. 6. A - Leiopus femoratus Fairm.; B - the map of the closest to Kaliningrad Oblast localities of L. femoratus in Europe known from literature [Ferenca, 2004; Gerend, Meyer, 2007; Teunissen, Jansen, 2009; Hegyessy, Kutasi, 2010; Zamoroka, Kapelyukh, 2012] (black points) and first report from Kaliningrad Oblast (green point); C - Rbamnusium bicolor bicolor (Schrnk) in nature; D - habitat of Rh. bicolor near Kornevo; $\mathrm{E}-$ habitat and collected specimen of Cotaster cf. cuneipennis (Aubé); $\mathrm{F}-$ the distribution map of C. cuneipennis in Europe known from literature [Diotti et al., 2015, 2019] (blue area) and the actual locality in Kaliningrad Oblast (red point).

Fig. 6. A - Leiopus femoratus Fairm. ; В - карта ближайших к Калининградской области мест сбора L. femoratus в Европе по питературным данным [Ferenca, 2004; Gerend, Meyer, 2007; Teunissen, Jansen, 2009; Hegyessy, Kutasi, 2010; Zamoroka, Kapelyukh, 2012] (чёрные точки) и первая находка вида в Калининградской области (зелёная точка); С - Rhamnusium bicolor bicolor (Schrnk) ; D - биотоп Rh. bicolor окомо Корнево; Е - биотоп и коммекционный экземпляр Cotaster cf. cuneipennis (Aubé); F - карта современного распространения вида C. cuneipennis в Европе по китературным данным [Diotti et al., 2015, 2019] (синяя заливка) и современное место сбора в Калининградской обкасти (красная точка). 
Gabriš R. 2013. Recent occurrence of Phaleria cadaverina (Fabricius, 1792) (Coleoptera: Tenebrionidae) on the Baltic coast of Poland // Baltic Journal of Coleopterology. Vol.13. No.2. P.121-124.

Gerend R., Meyer M. 2007. Leiopus femoratus Fairmaire, $1859-$ ein für Mitteleuropa neuer Bockkäfer in Luxemburg und im Saarland (Coleoptera: Cerambycidae) // Mitteilungen der Arbeitsgemeinschaft Rheinischer Koleopterologen (Bonn). Bd.17. Heft1-2. S.7-13.

Hegyessy G., Kutasi Cs. 2010. First record of Leiopus femoratus Fairmaire, 1859 in Hungary (Coleoptera: Cerambycidae) // Folia Entomologica Hungarica. Vol.71. P.43-45.

Hetmański T., Aleksandrowicz O., Ziółkowski M. 2009. Bycznik Typhaeus typhoeus L. (Coleoptera, Geotrupidae) w pokarmie sowy uszatej Asio otus L. na Pomorzu Środkowym. // Chrońmy Przyrodę Ojczystą. Vol.65. No.3. P.213-218.

Kubisz D. 2006. Oedemeridae i Scraptiidae Polski (Coleoptera, Tenebrionoidea). Monografie Faunistyczne. Vol. 24. Kraków: PAN. $165 \mathrm{p}$.

Lentz F.L. 1879. Catalog der Preussischen Käfer neu bearbeitet // Beiträge zur Naturkunde Preussens. No.4. P. 1-64.

Muona J. 1995. The European Isorhipis species (Coleoptera, Eucnemidae) // Entomologische Blätter. Bd.91. Heft3. S.159164.

Oleksa A., Gawroñski R., Ulrich W. 2009. Association of Ovalisia rutilans (Fabricius, 1777) (Coleoptera: Buprestidae) with thermophilous habitats toward its range edge in northern Poland // Baltic Journal of Coleopterology. Vol.9. No.1. P.39-44.

Petrov A.V. 2018. A key to genera and species of the tribe Hylesinini Erichson, 1836 (Coleoptera: Curculionidae: Scolytinae) from Russia and adjacent countries // Russian Entomological Journal. Vo.27. No.2. P.179-189.

Ruta R., Jałoszyński P., Sienkiewicz P., Konwerski S. 2011. Erotylidae (Insecta, Coleoptera) of Poland - problematic taxa, updated keys and new records // ZooKeys. Vol.134. P.113.

Ryndevich S.K. 2016. Species of genus Hydrobius (Coleoptera: Hydrophilidae) from Belarus // Vestnik BarGU. Vol.4. P.6371 .
Ryndevich S.K. 2017. New faunistic records of Hydrophilid beetles (Coleoptera: Hydrophiloidea: Hydrophilidae) from Eurasia // Vestnik BarGU. Vol.5. P.65-70.

Scheers K., Mertens J., Thys N. 2014. On The occurrence of Suphrodytes dorsalis (Fabricius, 1787) and Suphrodytes figuratus (Gyllenhal, 1826) (Coleoptera: Dytiscidae) in Belgium with notes on the habitat // Bulletin de la Société royale belge d'Entomologie/Bulletin van de Koninklijke Belgische vereniging voor entomologie. Vol.150. P.187-189.

Silfverberg H. 2010. Enumeratio renovata Coleopterorum Fennoscandiae, Daniae et Baltiae // Sahlbergia. Vol.16. P.1144.

Szołtys H., Taszakowski A. 2017. Isorhipis nigriceps (Mannerheim, 1823) - nowy dla fauny Polski gatunek chrząszcza (Coleoptera: Eucnemidae). // Acta entomologica silesiana. Vol.25. P.1-5.

Tamutis V., Tamutë B., Ferenca R. 2011. A catalogue of Lithuanian beetles (Insecta, Coleoptera) // ZooKeys. Vol.121. P. 1-494.

Teunissen A.P.J.A., Jansen R.P. 2009. Noordwestelijke areaaluitbreiding van de kleine nevelvlekboktor Leiopus femoratus (Coleoptera: Cerambycidae) // Entomologische Berichten. Vol.69. No.1. P.13-15.

Tsinkevich V.A. 2005. Checklist of Cucujoidea (Coleoptera) of Belarus (Eastern Europe) // Contributions to Systematics and Biology of Beetles. Papers Celebrating the 80th Birthday of Igor Konstantinovich Lopatin. P.333-345.

Tsinkevich V. A., Aleksandrowicz O., Dąbkowski P. 2013. New record of Phaleria cadaverina cadaverina (Fabricius, 1792) (Coleoptera, Tenebrionidae) from Baltic Sea coast (West Polish Pomerania) // Baltic Coastal Zone. Vol.17. P.127-129.

Vorbringer G. 1902. Sammelbericht aus der Umgegend von Königsberg i. Pr. // Deutsche Entomologische Zeitschrift. Heft2. S.411-415.

Zamoroka A.M., Kapelyukh Y.I. 2012. The genus Leiopus Audinet-Serville, 1835 in Western Ukraine and the invading of Mediterranean-Pontic species Leiopus femoratus Fairmaire 1859 (Coleoptera: Cerambycidae: Acanthocinini) // Scientific Bulletin of the Uzhgorod University (Series Biology). Vol.32. P.60-64.

Поступила в редакцию 9.1.2020 